\title{
Detecção de anticorpos para Toxoplasma gondii, Nicolle \& Manceaux, 1909 em soros de suínos da região da Grande Porto Alegre - RS, Brasil, através das técnicas de imunofluorescência indireta (IFI) e hemaglutinação indireta (HAI)*
}

\author{
CRISTINA GERMANI FIALHO \\ Flávio Antônio Pacheco de Araujo (Orientador - UFRGS)
}

Banca: Carlos Marcos Barcellos de Oliveira (UFRGS), Silvia Maria Spalding (UFRGS), Maristela Lovato Flores (UFSM)

A toxoplasmose é uma doença causada por um parasita coccídio intracelular obrigatório o T. gondii. O estudo deste parasita na espécie suína é importante pois ele causa perdas econômicas devido a abortos, retardo no crescimento e mortalidade peri-natal. Além disso, o consumo da carne mal cozida ou crua desses animais é considerada uma importante fonte de infecção humana. Com o objetivo de contribuir com dados sobre a frequiência de anticorpos para T. gondii em suínos da Região da Grande Porto Alegre, foram quantificadas as freqüências de anticorpos da classe IgG anti- T. gondii em soros de suínos abatidos em frigoríficos dessa região, utilizando-se as técnicas de Hemaglutinação indireta (HAI) e Imunofluorescência indireta (IFI). A freqüência de anticorpos anti- T. gondii, para amostragem de 240 suínos foi de $20 \%$ pela técnica HAI e 33,75\% pela técnica IFI. A amostragem foi estratificada em dois grupos experimentais de acordo o sexo. No grupo I, composto por 120 machos, 10,42\% foram reagentes na HAI, enquanto 17,5\% reagiram na IFI. No grupo II, com 120 fêmeas, 9,58\% foram reagentes na HAI e 16,25\% reagiram a IFI. A porcentagem de co-positividade e co-negatividade nas duas técnicas foi de 48,1\% e 94,3\%, respectivamente, perfazendo uma porcentagem de concordância total de 78,7\%, enquanto o valor Kappa calculado foi de 0,46. Esses valores de freqüência de anticorpos são relativamente altos, o que leva a conclusão de que os suínos abatidos nesta região podem ser considerados uma fonte de transmissão de Toxoplasma gondii para seres humanos, quando sua carne for consumida mal cozida ou crua.

Descritores: Toxoplasma gondii, suínos, imunofluorescência indireta, hemaglutinação indireta.

Apresentada: 21 março 2002

* Dissertação de Mestrado no 326 (Especialidade: Protozoologia). 115f. Programa de Pós-Graduação em Ciências Veterinárias da Faculdade de Veterinária - UFRGS, Porto Alegre/RS. CORRESPONDÊNCIA: C. G. Fialho [crisgfia@bol.com.br ; cristinafialho@bol.com.br]. 


\title{
Detection of antibodies to Toxoplasma gondii, Nicolle \& Manceaux, 1909 in swine from the area of Great Porto Alegre, Brasil-RS, Brasil by indirect imnunofluorescence technique and indirect technique**
}

\author{
CRISTINA GERMANI FIALHO
}

Flávio Antônio Pacheco de Araujo (Adviser - UFRGS)

Committee: Carlos Marcos Barcellos de Oliveira (UFRGS), Silvia Maria Spalding (UFRGS), Maristela Lovato Flores (UFSM)

The toxoplasmosis is a disease caused by an intracellular obligatory coccid parasite, the Toxoplasma gondii. The study of this parasite in swine species is importante because it causes economical losses due to abortion, slow grow and death before parturition. Besides, these animals' undercook or raw meat comsuption is considered the biggest human infection source. With the objective of contribuiting on datas about antibodies' frequency to T. gondii in swine from the area of Great Porto Alegre, the frequency of antibodies IgG anti- T. gondii in swine sera slaughtered in slaughterhouses from that region, were quantified. The techniques used were indirect hemmaglutination and the indirect immunofluorescence. The anti-T. gondii antibody' frequency, to 240 swine sampling was $20 \%$ by the HAI technique and $33,75 \%$ (percent) by the IFI technique. Two esperimental groups were formed, according to the animals' sex. In Group I, with 120 males, $10.42 \%$ were HAI positive, while $17.5 \%$ were IFI reacting. In Group II, with 120 females $9.58 \%$ were HAI positive and $16.25 \%$ were IFI reacting. The agrrement percentage related in to positiviness and negativiness in both techniques was $78.8 \%$ being $48.1 \%$ co-positiviness and the $94.3 \%$ co-negativiness, while the kappa calculed was 0.46 . These antibody frequencies were relatively hight, that leads to the conclusion that swine slaughtered in this region may be considered a $T$. gondii source to humans, if the meat is comsumed undercook or raw.

Key words: Toxoplasma gondii, swine, indirect imunofluorescence, indirect hemaglutination. 